Chapter 12

\title{
Steroidal CYP17 Inhibitors for Prostate Cancer Treatment: From Concept to Clinic
}

\author{
Jorge A. R. Salvador, Vânia M. Moreira and \\ Samuel M. Silvestre \\ Additional information is available at the end of the chapter \\ http://dx.doi.org/10.5772/45948
}

\section{Introduction}

The successful application of therapeutic strategies to block the known growth stimulation property of estrogen in breast cancer, namely the aromatase (CYP19) inhibitors formestane (4-OH) and exemestane (Aromasin) [1], has paved the way for the investigation of inhibitors of other P450 enzymes that might impart the growth of hormone-dependent cancers [2]. Cytochrome P450 17 $\alpha$-hydroxylase, $\mathrm{C}_{17,20}$-lyase (CYP17) is at the crossroads of androgen and corticoid biosynthesis and has become a valuable target in prostate cancer (PC) treatment [3-8]. Androgens, which are produced in steroidogenic tissues, bind to the androgen receptor (AR) and initiate transcription which in turn results in the synthesis of prostate-specific proteins, as well as in cell proliferation. Systemic ablation of androgen by castration, either surgical or chemical, is highly effective in treating PC when the disease is hormone-dependent [3]. However, within 18-24 months following the onset of primary hormonal therapies, the disease becomes androgen-refractory by mechanisms in which AR-mediated signaling and gene expression is still active despite castrate androgen levels [9]. The FDA approved the combination of docetaxel (Taxotere) 1 and prednisone for the treatment of castrate-resistant PC (CRPC) which improves survival time in about 18 months [10, 11], and cabazitaxel (Jevtana) 2 [12], a novel taxane derivative, for metastatic CRPC (mCRPC) which has progressed following docetaxel therapy (Fig. 1). The immunotherapy Sipuleucel-T (Provenge) is also approved for the treatment of asymptomatic or minimally symptomatic mCPRC. In April 2011, abiraterone acetate (Zytiga) 3 became the first steroidal CYP17 inhibitor to be approved by the FDA for the treatment of docetaxel-resistant mCRPC (Fig. 1) [13, 14]. Following abirateroneacetate 3, galeterone (TOK-001) 4 (Fig. 1), another steroidal CYP17 inhibitor, 
with AR antagonistic and ablative activities, is currently undergoing Phase I/II clinical trials for the treatment of chemotherapy-naive CRPC $[15,16]$.
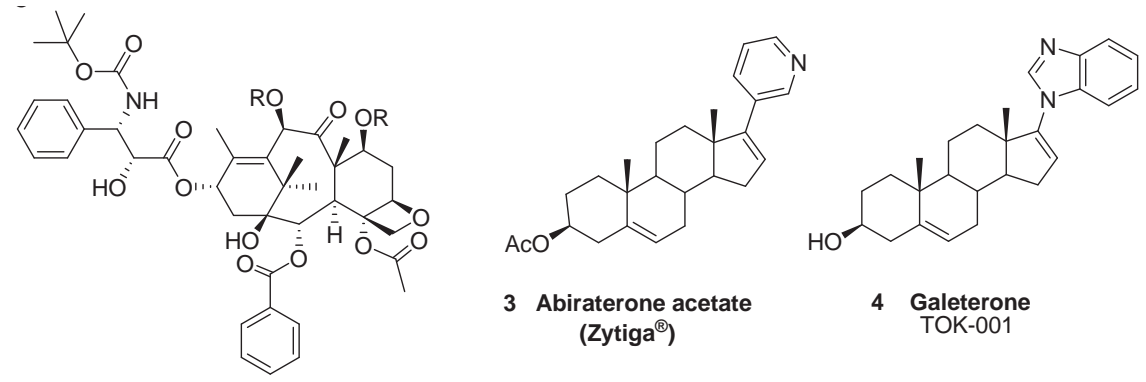

$1 \mathrm{R}=\mathrm{H} \quad$ Docetaxel $\left(\right.$ Taxotere $\left.^{\circledR}\right)$

$2 \mathrm{R}=\mathrm{CH}_{3} \quad$ Cabazitaxel (Jevtana ${ }^{\circledR}$ )

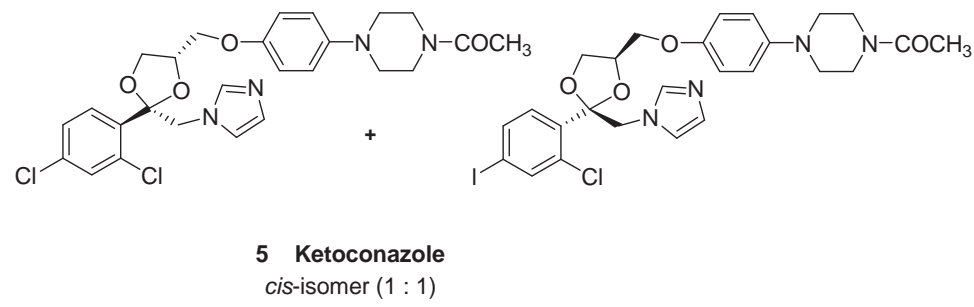

Figure 1. Compounds used in the clinical practice for PC treatment, and galeterone4, currently undergoing clinical trials for the treatment of chemotherapy-naive CRPC.

The first reports on steroidal CYP17 inhibitors date back to about 40 years ago [3, 8, 17-20]. Many different chemistries have been exploited in their development which has been complicated by the fact that no 3D structure of the enzyme is available. Nonetheless, structureactivity analysis has revealed the general features of a good inhibitor and recent docking and modeling studies have further shed some light on the way these molecules interact with the enzyme's active site [21, 22]. Moreover, additional effects of these compounds on other PC-related targets have been studied and disclosed. This chapter will tell the success story of the development of steroidal CYP17 inhibitors from their early discovery days to their very recent introduction into the clinics for the treatment of advanced PC.

\section{The CYP17 enzyme: One active site, two activities}

The eukaryotic class II cytochrome P450 enzyme CYP17 is an endoplasmic reticulum membrane bound multifunctional protein with $17 \alpha$-hydroxylase and $C_{17,20}$-lyase activities, both engaged on a single active site (Fig. 2) [23-28]. 


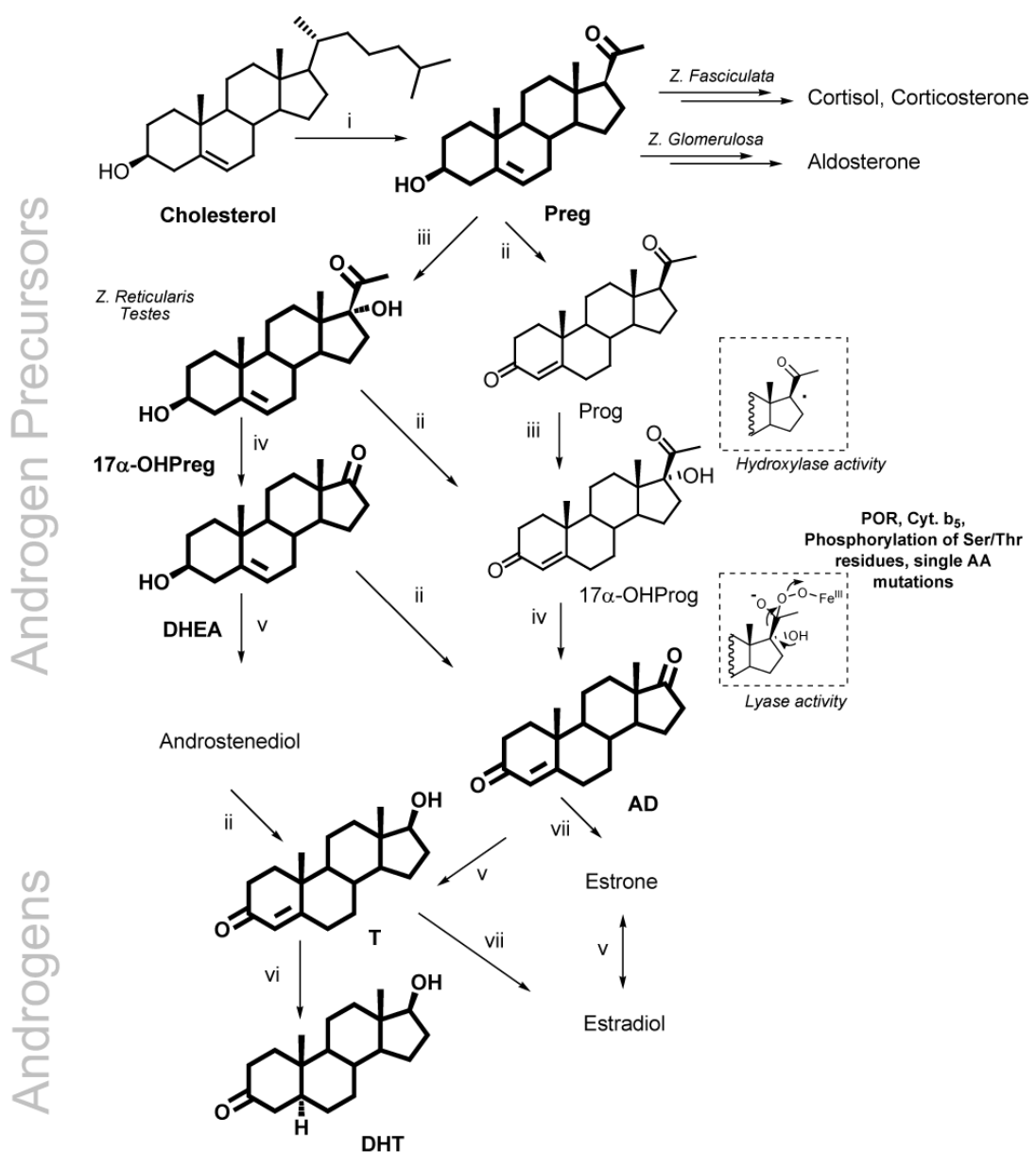

Figure 2. CYP17 and androgen physiology. i. P450 cholesterol side-chain cleavage ( $\mathrm{P}^{4} 5 \mathrm{O}_{\text {scc }}$ ); ii. $3 \beta$-Hydroxysteroid dehydrogenase, $\triangle^{4,5}$-isomerase; iii. CYP17 (OHase); iv. CYP17 (lyase); v. 17ß-Hydroxysteroid dehydrogenase; vi. 5a-Reductase; vii. Aromatase (CYP19).

Alike other cytochrome P450 enzymes, this cysteinato-heme enzyme functions as a monooxygenase by activating and cleaving molecular dioxygen so that one of the atoms is inserted into its substrate while the other gives rise to a water molecule [29, 30]. P450 reductase transfer of electrons in the presence of nicotinamide adenine dinucleotide phosphate (NADPH) is a requisite for both catalytic activities [29, 30]. Its natural substrates are pregnenolone (Preg) and progesterone (Prog) which are first hydroxylated at the 17 position and then their side chain is cleaved to afford 17-keto derivatives (dehydroepiandrosterone, DHEA and androstenedione, AD respectively), which are androgen precursors. The androgens (testosterone, $\mathrm{T}$ and dihydrotestosterone, $\mathrm{DHT}$ ) that result from further metabolization of both DHEA and AD, bind to the $\mathrm{AR}$ and initiate transcription, triggering the synthesis of 
specific proteins and also cell proliferation [31, 32]. Apart from male physiology, androgens are involved in PC development and progression, as at least $80 \%$ of human PCs respond favorably to androgen ablation therapy [33-35]. This dependence of PC on androgen signalling has been known for about 70 years $[36,37]$ and the use of strategies that effectively lower the levels of circulating androgens in PC patients has been the mainstay of PC therapy for several decades.

CYP17 is localized to the adrenals, testes, placenta and ovaries and plays a fundamental role in the synthesis of not only sex steroids but also corticosteroids. The testes are responsible for about $90-95 \%$ of the circulating androgens and the adrenals for the remaining $5-10 \%$ [38]. Human CYP17 is expressed from a single gene mapped to a specific sub-band of chromosome 10 at q24.3, in steroidogenic tissue [39-41]. This bifunctionality of the product of a single gene has been explained by modulation of the enzyme's $C_{17,20}$-lyase activity by several factors such as the presence of the electron carrier P450 oxidoreductase (POR) [42, 43], cytochrome b5 (cyt. b5) [44-48], the phosphorylation of serine/threonine residues [44, 49-51], and single amino acid mutations [52-55]. The effective ratio of $\mathrm{C}_{17,20}$-lyase to $17 \alpha$-hydroxylase activities is under tight control during development in the human adrenal cortex, and becomes greatly elevated in adrenarche, where a rise in DHEA body concentrations is observed without concomitant increase in glucocorticoid or mineralocorticoid production [56]. Thus, production of the mineralocorticoid aldosterone occurs in the adrenal zona glomerulosa where CYP17 is absent. In the zona reticularis and in the gonads, the presence of both activities drives the production of sex steroids, whereas overexpression of $17 \alpha$-hydroxylase activity is fundamental for the production of glucorticoids in the zona fasciculata.

The crystal structure of CYP17 remains yet to be determined since purification from its membrane environment and subsequent reconstitution of activity in vitro has proved to be a difficult task [26, 29, 30]. However, the availability of some cytochrome P450 crystal structures, such as the ones from prokaryotic P450cam [57, 58], P450BM3 [59-61], and P450 CYPeryF [62], as well as the eukaryotic CYP3A4 [63] and AYP2C9 [64] among others [65], has been a valuable tool in building homology models. In addition, the high-resolution crystal structures of mammalian P450s that are significantly homologous to CYP17 and complexed to a variety of ligands [66] have now been uploaded onto the Protein Data Bank (PDB). A very recent model has been developed based on these crystal structures from closely related mammalian cytochrome P450s [21]. In another approach, a truncated, His-tagged version of human CYP17 was generated from a synthetic complimentary DNA and expressed in E. coli [22]. These models were used to dock known CYP17 inhibitors to the active site.

\section{Steroidal CYP17 inhibitors}

Clinical practice outcomes with ketoconazole 5 (Fig. 1), an orally administered non-steroidal imidazole antifungal agent that was first reported to cause gynecomastia in male patients [67-69], have further evidenced the value of inhibition of the steroid synthesis pathway as a therapeutic strategy for advanced PC. This compound is used clinically as the racemate of 
the cis-isomer [17, 70], and is offered as secondary hormonal therapy to patients with CRPC, despite some significant gastrointestinal and hepatic side-effects when administered in high doses [71-73]. Following ketoconazole 5, several non-steroidal compounds have been synthesized which displayed better inhibitory properties. In addition, modification of the original core of the enzyme's natural substrates has also afforded very potent steroidal inhibitors $[3,8,17-20]$. Based on the knowledge that was generated by this approach which was recently validated by computational studies, common features were established for optimal interaction between enzyme and substrate. Thus, a good inhibitor should possess a sufficiently large hydrophobic core, comparable to a steroid molecule, and bear electronegative groups at its external positions [74]. The presence of a heteroatom-containing group capable of coordination to the heme iron of CYP17, ofa planar $\alpha$-face to pack against the I helix; and in addition of hydrogen bonding groups such as the $3 \beta$-hydroxylto interact with conserved polar residues in a hydrogen binding network, has proved invaluable for optimal inhibition, as is the case of both abiraterone acetate 3 and galeterone 4 [22].

\subsection{Androstanes}

The first reports on CYP17 steroidal inhibitors date back to 1971 when Arth et al. synthesized and evaluated testosterone derivatives against rat testicular CYP17, following the observation that testosterone acetate 6 (Fig. 3, Table 1, entry 1) was a potent inhibitor of the enzyme [75]. Almost total abrogation of the enzyme's activity was observed after treatment with $1.5 \mu \mathrm{M}$ of compounds 7, 8, and 10 (Table 1, entries 2-3, and 5), with the acetamide derivative 9 being less potent (Table 1, entry 4). Competitive inhibition of pig CYP17 was reported for the anabolic steroids mestanolone 11, stanozolol12, and furazobol 13 (Fig. 3) [76]. Week inhibition in the high $\mu \mathrm{M}$ range was found with compounds 11 and 13 against the $\mathrm{C}_{17,20}$-lyase activity whereas stanozolol 12 inhibited both enzyme activities with $\mathrm{IC}_{50}$ values of $2.9 \mu \mathrm{M}$ and $0.74 \mu \mathrm{M}$, for the $17 \alpha$-hydroxylase and $\mathrm{C}_{17,20}$-lyase activities, respectively.

The irreversible inhibition of CYP17 by compound 14 (Fig. 3, Table 1, entry 6) was reported to occur due to the presence of a cyclopropylamino moiety capable of being activated by the enzyme by one-electron oxidation of the nitrogen atom, which causes ring opening to afford a $\beta$-iminium radical that covalently binds to the enzyme, while the compound is still bound in the active site [77]. Other related irreversible inhibitors reported include compounds 15-18 (Fig. 3, Table 1, entries 7-10) [78-81]. Compounds 15-17 were potent inhibitors of the human CYP17 at 0.8 and $1 \mu \mathrm{M}$, after preincubation with the enzyme (Table 1, entries 7-9). The ki values of the 4-amino derivatives 16-17 and of the sulfoxide derivatives 19-20 were determined using cynomolgous monkey and porcine testicular CYP17, respectively (Table 1, entries 8-9 and 11-12) [82]. Compound 18 also potently inhibited the activity of the monkey cynomolgous CYP17 at $0.1 \mu \mathrm{M}$, after preincubation with the enzyme (Table 1, entry 10) [80].

The introduction of heterocyclic moieties into molecules is a commonly used strategy in drug discovery and the design of potent steroidal CYP17 inhibitors based on this feature is an example of success. Thus, several androstane derivatives have been synthesized bearing a heterocycle ring at C17 either connected to it by a carbon (Fig. 4, Compounds 21-50) or a nitrogen (Fig. 5, Compounds 53-60) atom. In 1995, Jarman et al. reported the synthesis of 
abiraterone 21 (Fig. 4), a 17-(3-pyridyl)androstane derivative and a potent irreversible inhibitor of human testicular CYP17 (Table 2, entry 1), about 16- and 9-fold more potent than ketoconazole 5 for the inhibition of the hydroxylase and lyase activities, respectively, with $\mathrm{IC}_{50}$ values in the low $\mathrm{nM}$ range [86]. Its $3 \beta$-acetoxy derivative and prodrug, abiraterone acetate 3 (Table 2, entry 2) has helped to further evidence and establish the utility of specific CYP17 inhibition in metastatic PC (mPC) patients. In 2001, Hartmann et al. reported that the introduction of a pyrimidyl substituent at C17 originated compounds such as 22 and 23 (Fig. 4, Table 2, entries 3-4) which were more potent inhibitors of the human enzyme than both ketoconazole 5 and abiraterone 21, under the same assay conditions, and that compound 23 effectively lowered $\mathrm{T}$ plasma concentrations to castrate levels after administration to mice $[87,88]$. The thiazole and furan derivatives 24 and 25 were also synthesized and tested on the monkey cynomolgous enzyme (Fig. 4, Table 1, entries 13-14) [83, 85].

\begin{tabular}{|c|c|c|c|c|c|c|}
\hline Entry & Compound & $\begin{array}{c}\text { Inhibitor } \\
\text { concentration }(\mu \mathrm{M})\end{array}$ & $\%$ Inhibition $^{a}$ & $\mathrm{Ki}(\mathrm{nM})$ & $\mathrm{IC}_{50}(\mu \mathrm{M})$ & Ref. \\
\hline 1 & 6 & 1.5 & 65 & - & - & \multirow{5}{*}{ [75] } \\
\hline 2 & 7 & 1.5 & 95 & - & - & \\
\hline 3 & 8 & 1.5 & 100 & - & - & \\
\hline 4 & 9 & 1.5 & 85 & - & - & \\
\hline 5 & 10 & 1.5 & 90 & - & - & \\
\hline 6 & 14 & - & - & $90^{\mathrm{b}}$ & $4.6^{c}$ & [77] \\
\hline 7 & 15 & 0.8 & 64 & - & - & {$[78,79]$} \\
\hline 8 & 16 & 1 & 84 & $339^{b}$ & - & \multirow{2}{*}[80,81]{} \\
\hline 9 & 17 & 1 & 86 & $286^{b}$ & - & \\
\hline 10 & 18 & 0.1 & $79^{b}$ & - & - & {$[80]$} \\
\hline 11 & 19 & - & - & $380^{c, d}$ & $1.9^{c}$ & \multirow{2}{*}{ [82] } \\
\hline 12 & 20 & - & - & $380^{c, d}$ & $1.9^{c}$ & \\
\hline 13 & 24 & 0.1 & $58^{b}$ & - & $0.063^{b}$ & \multirow{2}{*}[83-85]{} \\
\hline 14 & 25 & 0.1 & $53^{b}$ & - & - & \\
\hline
\end{tabular}

Table 1. Inhibition of CYP17 by androstane derivatives. ${ }^{a}$ Human CYP17; b Determined on cynomolgous monkey testis

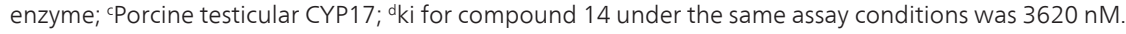

A series of interesting effects on PC cells other than just CYP17 inhibition was reported by Brodie et al. for the imidazolyl, pyrazolyl, and isoxazolylandrostane derivatives 26-32 (Fig. 4, Table 2, entries 5-11). The isoxazolyl compound 32 was not only a non-competitive inhibitor of human CYP17 but also a competitive inhibitor of $5 \alpha$-reductase, with potency similar to finasteride, while in addition bearing antiandrogenic activity [89-93]. Its effects were confirmed using PC xenograftmodels, however, its short half-life and rela- 
tively low bioavailability were reasoned to limit its efficacy in vivo [93-95]. Less successful attempts of CYP17 inhibitors design include the 5'-methyl-2'-thiazolyl androstane 33 (Fig. 4) which was a weak inhibitor of human CYP17 expressed in E. coli when compared to ketoconazole 5 [3]. In 2006, Wolfling et al. reported the synthesis of a series of dihydrooxazine derivatives $34-45$ (Fig. 4) which low inhibitory activity of CYP17 is most likely due to the bulkiness of the C17 moieties and the absence of a double bond at C16 [96]. The same group later reported the synthesis of the oxazolidone derivative 46 (Fig. 4 , Table 2, entry 12) which inhibited the activity of rat testicular $\mathrm{C}_{17,20}$-lyase with an $\mathrm{IC}_{50}$ value of $3 \mu \mathrm{M}$ [97]. Similar inhibition of the enzyme was observed with the halogenated oxazoline derivatives 47 and 48 [98], and with the D-ring fused arylpyrazoline 51 (Fig. 4, Table 2, entries 13-14, and 17) [99]. The $N$-phenylpyrazolyl derivatives 49 and 50 were however much less active, with $\mathrm{IC}_{50}$ values in the high $\mu \mathrm{M}$ range [100], as was the steroidal D-ring fused oxazolidine 52 (Fig. 4, Table 2, entries 15-16, and 18) [99].
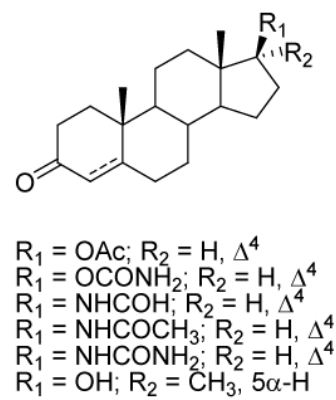

6
7
8
9
10
11

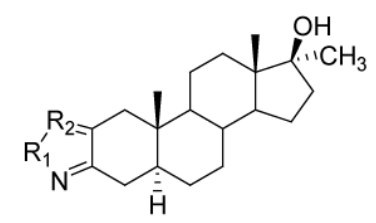

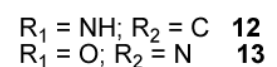<smiles>[R2]C1=C2C=CC3C(CCC4(C)C([R1])CCC34)C2(C)CCC1[R]</smiles><smiles>CS(=O)[C@H]1CCC2C3CC=C4CC(O)CCC4(C)C3CC[C@]21C</smiles><smiles>CS(=O)[C@H]1CCC2C3CC=C4CC(O)CCC4(C)C3CC[C@]21C</smiles>

$$
\begin{array}{ll}
\mathrm{R}_{1}=\mathrm{NH} ; \mathrm{R}_{2}=\mathrm{H}_{2} ; \mathrm{R}_{3}=\beta-\mathrm{OH} ; \Delta^{5} & 14 \\
\mathrm{R}_{1}=\mathrm{O} ; \mathrm{R}_{2}=\mathrm{H}_{2} ; \mathrm{R}_{3}=\beta-\mathrm{OH} ; \Delta^{5} & 15 \\
\mathrm{R}_{1}=\mathrm{O} ; \mathrm{R}_{2}=\mathrm{NH}_{2} ; \mathrm{R}_{3}=\mathrm{O} ; \Delta^{4,6} & 16 \\
\mathrm{R}_{1}=\mathrm{O} ; \mathrm{R}_{2}=\mathrm{NH}_{2} ; \mathrm{R}_{3}=\mathrm{O} ; \Delta^{4} & 17 \\
\mathrm{R}_{1}=\mathrm{O} ; \mathrm{R}_{2}=\mathrm{NO}_{2} ; \mathrm{R}_{3}=\mathrm{O} ; \Delta^{4} & \mathbf{1 8}
\end{array}
$$

Figure 3. Androstane based CYP17 inhibitors.

In 1996, Njar et al. reported the first steroidal inhibitors of CYP17 bearing a heterocyclic moiety bound to C17 by a nitrogen atom [101], which included compounds 53-55 (Fig. 5, Table 2, entries 19-21), among which the imidazolyl derivative 53 was found to be the most promising [101-104]. Later, in 2005, the same group reported the synthesis of galeterone 4 and its $\Delta^{4}$-3-keto derivative 56 (Fig. 5, Table 2, entries 22-23) [104-106]. 


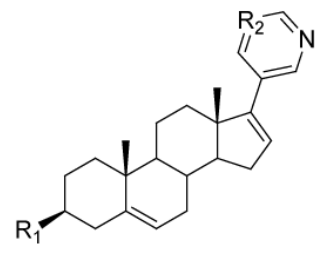

$\mathrm{R}_{1}=\mathrm{OH} ; \mathrm{R}_{2}=\mathrm{CH} \quad \mathbf{2 1}$

$\mathrm{R}_{1}=\mathrm{OH} ; \mathrm{R}_{2}=\mathrm{N} \quad 22$

$\mathrm{R}_{1}=\mathrm{OAC} ; \mathrm{R}_{2}=\mathrm{N} \quad \mathbf{2 3}$

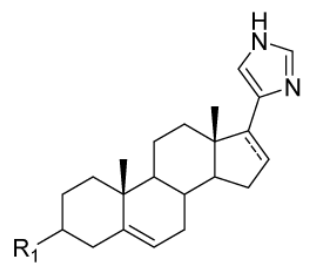

$\begin{array}{ll}\mathrm{R}_{1}=\beta-\mathrm{OH} ; \Delta^{5} & \mathbf{2 6} \\ \mathrm{R}_{1}=\beta-\mathrm{OH} ; \Delta^{5,16} & \mathbf{2 7}\end{array}$

$\begin{array}{ll}\mathrm{R}_{1}=\beta-\mathrm{OH}_{3} ; \Delta^{5,16} & \mathbf{2 7} \\ \mathrm{R}_{1}=\mathrm{O} ; \Delta^{4} & \mathbf{2 8}\end{array}$

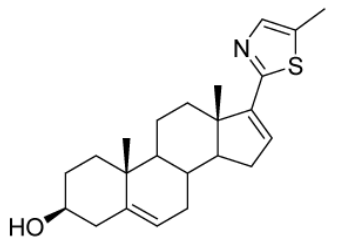

33

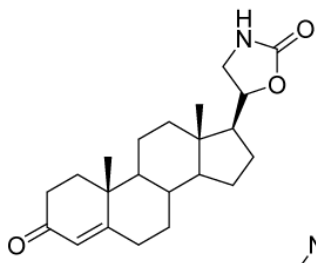

46

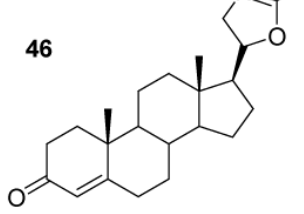

$\mathrm{R}_{1}=\mathrm{Cl}, \mathrm{R}_{2}=\mathrm{H}$

$\mathrm{R}_{1}=\mathrm{H} ; \mathrm{R}_{2}=\mathrm{Br}$

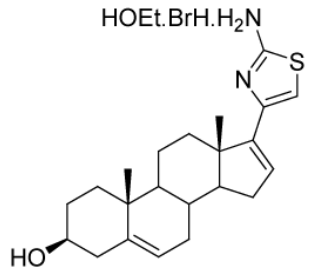

24<smiles>C[C@]12CCC3C(CC=C4C[C@H](O)CC[C@@]43C)C1CC=C2C1N=CC=N1</smiles>

29<smiles>[R]C1=NCC[C@H]([C@H]2CC[C@H]3[C@@H]4CC=C5C[C@@H](O)CC[C@]5(C)[C@H]4CC[C@]32C)O1</smiles>

\section{$\mathrm{R}=\mathrm{Ph}$}

$\mathrm{R}=$ 4-chlorophenyl

$\mathrm{R}=4$-bromophenyl

$\mathrm{R}=4$-nitrophenyl

$\mathrm{R}=4$-methoxyphenyl

$\mathrm{R}=3,4,5$-trimethoxyphenyl 39<smiles>C[C@]12CCC3C(CC=C4C[C@H](O)CC[C@@]43C)C1CC=C2c1ccoc1</smiles>

25<smiles>[R][R]c1cc[nH]c1C1=CCC2C3CC=C4C=C([R3])CC[C@]4(C)[C@H]3CC[C@]12C</smiles>

$\mathrm{R}_{1}=\mathrm{N} ; \mathrm{R}_{2}=\mathrm{NH} ; \mathrm{R}_{3}=O A C \quad 30$

$R_{1}=N ; R_{2}=N H ; R_{3}=0 ; \Delta^{4} \quad 31$

$\mathrm{R}_{1}=\mathrm{N} ; \mathrm{R}_{2}=\mathrm{O} ; \mathrm{R}_{3}=\mathrm{O} ; \Delta^{4} \quad 32$<smiles>[R]C1=N[C@H]([C@H]2CC[C@H]3[C@@H]4CC=C5C[C@@H](O)CC[C@]5(C)[C@H]4CC[C@@]23C)CCO1</smiles>

$\mathrm{R}=\mathrm{Ph}$

$\mathrm{R}=$ 4-chlorophenyl

$\mathrm{R}=$ 4-bromophenyl

$\mathrm{R}=4$-nitrophenyl

$\mathrm{R}=4$-methoxyphenyl

$R=3,4,5$-trimethoxyphenyl

40

41

42

43

44 


\begin{tabular}{|c|c|c|c|}
\hline Entry & Compound & CYP17 inhibition (nM) & Ref. \\
\hline \multirow{2}{*}{1} & \multirow{2}{*}{21} & Human (OHase): 4 & \multirow{4}{*}[86,107]{} \\
\hline & & Human (lyase): 2.9 & \\
\hline \multirow{2}{*}{2} & \multirow{2}{*}{3} & Human (OHase): 18 & \\
\hline & & Human (lyase): 17 & \\
\hline \multirow{3}{*}{3} & \multirow{3}{*}{22} & Rat: 220 & \multirow{6}{*}[87,88]{} \\
\hline & & Human: 24 & \\
\hline & & E.coli a: 30 & \\
\hline \multirow{3}{*}{4} & \multirow{3}{*}{23} & Rat: 1460 & \\
\hline & & Human: 38 & \\
\hline & & E.colia: 2500 & \\
\hline \multirow{2}{*}{5} & \multirow{2}{*}{26} & Rat: 91 & \multirow{14}{*}[89,90]{} \\
\hline & & Human: 66 & \\
\hline \multirow{2}{*}{6} & \multirow{2}{*}{27} & Rat: 49 & \\
\hline & & Human: 24 & \\
\hline \multirow{2}{*}{7} & \multirow{2}{*}{28} & Rat: 79 & \\
\hline & & Human: 58 & \\
\hline \multirow{2}{*}{8} & \multirow{2}{*}{29} & $N D^{b}$ & \\
\hline & & Human: 21 & \\
\hline \multirow{2}{*}{9} & \multirow{2}{*}{30} & Rat: 28 & \\
\hline & & Human: 42 & \\
\hline \multirow{2}{*}{10} & \multirow{2}{*}{31} & Rat: 76 & \\
\hline & & Human: 59 & \\
\hline \multirow{2}{*}{11} & \multirow{2}{*}{32} & Rat: 32 & \\
\hline & & Human: 39 & \\
\hline 12 & 46 & Rat: 3000 & [97] \\
\hline 13 & 47 & Rat: 4800 & \multirow{2}{*}{ [98] } \\
\hline 14 & 48 & Rat: 5000 & \\
\hline 15 & 49 & Rat: 22000 & \multirow{2}{*}[100]{} \\
\hline 16 & 50 & Rat: 59000 & \\
\hline 17 & 51 & Rat: 5800 & [001 \\
\hline 18 & 52 & Rat: 26000 & [99] \\
\hline & & Rat: 9 & \\
\hline 19 & 53 & Human: 8 & \\
\hline & & LNCaP-CYP17 cellsc: 1.25 & \\
\hline & & Rat: 8 & [102 103 \\
\hline 20 & 54 & Human: 7 & {$[102,103]$} \\
\hline & & LNCaP-CYP17 cellsc: 2.96 & \\
\hline 21 & 55 & Rat: 10 & \\
\hline & & Human: 13 & \\
\hline
\end{tabular}




\begin{tabular}{cccc}
\hline Entry & Compound & CYP17 inhibition (nM) & Ref. \\
\hline & & LNCaP-CYP17 cells $:$ : 7.97 & {$[105,106]$} \\
\hline 22 & 4 & E.colia: 300 & \\
\hline 23 & 56 & E.colia: 915 & {$[4]$} \\
\hline 25 & 61 & LNCaP-CYP17 cells $\mathrm{s}: 11500$ & \\
\hline
\end{tabular}

Table 2. $I C_{50}$ values for androstane CYP17 inhibitors. ${ }^{a}$ Recombinant human CYP17 expressed in E.coli; ${ }^{b} \mathrm{ND}=$ Not Determined; 'Recombinant human CYP17 expressed in LNCaP cells.

Thus, in vitro results with compounds 53-55 revealed a high inhibitory potential of the human enzyme expressed in LNCaP cells. In addition, compounds 53 and 55 completely suppressed T and DHT stimulated growth of LNCaP cells below $5 \mu \mathrm{M}$, and displayed antiandrogenic activity $[102,108]$. In vivo experiments confirmed these results and showed that the compounds were however less effective than castration [109]. The C17-benzimidazole derivative 4 became the first example of a CYP17 inhibitor and antiandrogen that could effectively suppress androgen-dependent tumor growth better than castration [105]. In 2007, our group reported the synthesis of the $1 \mathrm{H}$ - and $2 \mathrm{H}$-indazole androstanes 57-60 which despite being poor inhibitors of human CYP17 displayed selective inhibition of PC-3 cells suggesting that mechanisms other than interference with the AR could be involved in their cytotoxicity [5]. We also synthesized a series of steroidal carbamates out of which compounds 61 and 62 (Fig. 5, Table 2, entries 24-25) were inhibitors of human CYP17 with $\mathrm{IC}_{50}$ values of 11.5 and $17.1 \mu \mathrm{M}$, respectively [4].

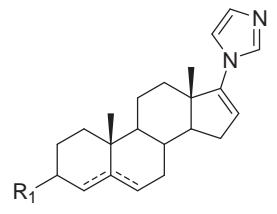

$\mathrm{R}_{1}=\beta-\mathrm{OH} ; \Delta^{5} \quad 53$ $\mathrm{R}_{1}=\mathrm{O} ; \Delta^{4}$

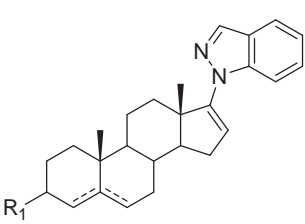

$\mathrm{R}_{1}=\beta-\mathrm{OH} ; \Delta^{5} \quad 57$
$\mathrm{R}_{1}=\mathrm{O} ; \Delta^{4}$

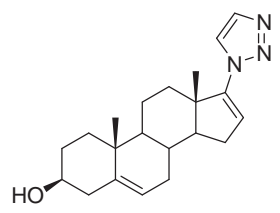

55

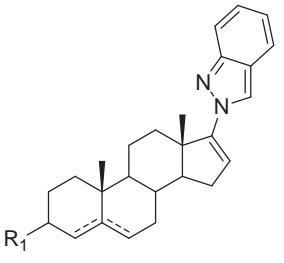

$\mathrm{R}_{1}=\beta-\mathrm{OH} ; \Delta^{5} \quad 59$

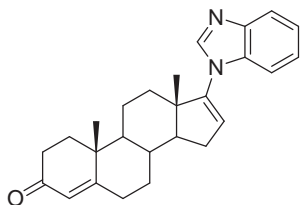

56<smiles>Cc1nccn1C(=O)OC1CCC2C3CC=C4C=CC(Br)C=CC4(C)C3CCC12C</smiles>

$\begin{array}{ll}\mathrm{R}_{1}=\beta-\mathrm{OH} ; \Delta^{5} & 61 \\ \mathrm{R}_{1}=\mathrm{O} ; \Delta^{1,4} & 62\end{array}$

Figure 5. Androstane based CYP17 inhibitors. 


\subsection{Pregnanes}

Among the pregnane CYP17 inhibitors, compounds 63-65 (Fig. 6, Table 3, entries 1-3) bearing 20-substituents with moderate to strong dipole properties were more active than ketoconazole in inhibiting human CYP17, displaying $\mathrm{IC}_{50}$ values of 16 to $230 \mathrm{nM}$ and 16 to $190 \mathrm{nM}$ for the hydroxylase and lyase activities, respectively [90, 110, 111]. In 2000, Hartman et al. tested several pregneneoximes 66-76 among which some were potent inhibitors of both rat and human CYP17 (Fig. 6, Table 3, entries 4-11) [112]. Compound 66 was effective in vivo and suppressed plasma $\mathrm{T}$ concentrations more potently than ketoconazole. The hydroxamic acid derivative 77 (Fig. 6) was not a CYP17 inhibitor [113].

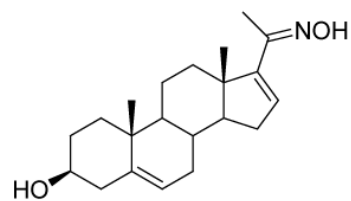

63

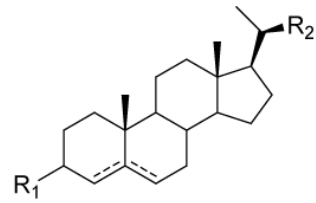

$\mathrm{R}_{1}=\mathrm{R}_{2}=\beta-\mathrm{OH} ; \Delta^{5} \quad 64$

$\mathrm{R}_{1}=\mathrm{O} ; \mathrm{R}_{2}=\mathrm{CHO} ; \Delta^{4}$<smiles>[R]C1C=C2CCC3C(CCC4(C)C(=CC(=O)O)CCC34)C2(C)CC1</smiles>

(1: 1)<smiles>[R7]C1C=C2CCC3C4=CC=C(C(C)=NO)[C@@]4(C)CCC3[C@@]2(C)CC1</smiles>

$\mathrm{R}_{1}=\beta-\mathrm{OH} ; \Delta^{5} \quad 69$

$\mathrm{R}_{1}=\mathrm{O} ; \Delta^{4} \quad 70$

$\mathrm{R}_{1}=\beta-\mathrm{OH} ; \Delta^{5,14} \mathbf{7 1}$

$\mathrm{R}_{1}=\mathrm{O} ; \Delta^{4,14} \quad 72$<smiles>[R]C1C=C2CCC3C(=CC[C@@H]3C(C)=N)[C@@]2(C)CC[C@H]1C</smiles>

$17 \beta ; \mathrm{R}_{1}=\beta-\mathrm{OH} ; \Delta^{5} \quad 73$

$17 \beta ; R_{1}=0 ; \Delta^{4}$ $17 \alpha ; \mathrm{R}_{1}=\beta-\mathrm{OH} ; \Delta^{5} \quad 75$

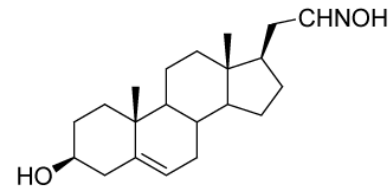

76<smiles>C[C@]12CC[C@@H](O)CC1=CCC1C2CC[C@]2(C)C1CC[C@H]2C(O)=NO</smiles>

77

Figure 6. Pregnane based CYP17 inhibitors. 


\begin{tabular}{|c|c|c|c|}
\hline Entry & Compound & CYP17 inhibition (nM) & Ref. \\
\hline \multirow{2}{*}{1} & \multirow{2}{*}{63} & Human (OHase): 16 & \multirow{4}{*}[90,110,111]{} \\
\hline & & Human (lyase): 16 & \\
\hline \multirow{2}{*}{2} & \multirow{2}{*}{64} & Human (OHase): 180 & \\
\hline & & Human (lyase): 190 & \\
\hline \multirow{2}{*}{3} & \multirow{2}{*}{65} & Human (OHase): 230 & \multirow{2}{*}[90,110,111,114]{} \\
\hline & & Human (lyase): 160 & \\
\hline \multirow{3}{*}{4} & \multirow{3}{*}{66} & Rat: 520 & \multirow{19}{*}[112]{} \\
\hline & & Human: 77 & \\
\hline & & E. coli b: 230 & \\
\hline \multirow{2}{*}{5} & \multirow{2}{*}{67} & Rat: 140 & \\
\hline & & Human: 180 & \\
\hline \multirow{3}{*}{6} & \multirow{3}{*}{69} & Rat: ${ }^{a}$ & \\
\hline & & Human: 170 & \\
\hline & & E. coli b: 520 & \\
\hline \multirow{2}{*}{7} & \multirow{2}{*}{70} & Rat: $^{a}$ & \\
\hline & & Human: 100 & \\
\hline \multirow{3}{*}{8} & \multirow{3}{*}{71} & Rat: $^{a}$ & \\
\hline & & Human: 200 & \\
\hline & & E. coli b: 420 & \\
\hline \multirow{2}{*}{9} & \multirow{2}{*}{72} & Rat: $^{a}$ & \\
\hline & & Human: 200 & \\
\hline \multirow{2}{*}{10} & \multirow{2}{*}{74} & Rat: 300 & \\
\hline & & Human: 300 & \\
\hline \multirow{2}{*}{11} & \multirow{2}{*}{76} & Rat: 2760 & \\
\hline & & Human: 270 & \\
\hline \multirow{2}{*}{12} & \multirow{2}{*}{78} & Rat: 210 & \multirow{4}{*}[115,116]{} \\
\hline & & Human: 540 & \\
\hline 13 & 79 & Rat: 34000 & \\
\hline & 19 & Human: 1520 & \\
\hline 14 & 80 & Rat: 1200 & [4 \\
\hline 15 & 81 & Rat: 36000 & \\
\hline 16 & 78 & Rat: 9670 & \\
\hline 10 & 02 & Human: 970 & \\
\hline 17 & 83 & Rat: 430 & [116] \\
\hline (1) & 03 & Human: 290 & {$[1116]$} \\
\hline 18 & 81 & Rat: 530 & \\
\hline 10 & 04 & Human: 400 & \\
\hline
\end{tabular}




\begin{tabular}{cccc}
\hline Entry & Compound & CYP17 inhibition (nM) & Ref. \\
\hline 19 & 85 & Rat (OHase): 75.8 & {$[117]$} \\
\hline 20 & 86 & Rat (lyase): 55.8 & {$[118]$} \\
\hline
\end{tabular}

Table 3. $I C_{50}$ values for pregnane CYP17 inhibitors. ${ }^{a} \geq 125 \mu \mathrm{M}$; ${ }^{b} E$. Coli cells coexpressing human CYP17 and NADPH reductase

A difference in the inhibitory potential of rat CYP17 of the aziridinylpregnanes 78-81 was observed between the $S$ - and $R$-isomers, the $S$-isomers 78 and 80 being 162 and 30 -fold more potent than the $R$-isomers, respectively (Fig. 7, Table 3, entries 12-15) [115]. However, this finding was not corroborated by later studies that used the human enzyme [116]. The activity of compounds 82-85 (Fig. 7, Table 2, entries 16-19) was also reported [116, 117]. Several fluorinated pregnanes 86-91and 93 were synthesized in search of greater metabolic stability (Fig. 7, Table 3, entry 20, Table 4). Inhibition of the cynomolgous monkey enzyme at $1 \mu \mathrm{M}$, following preincubation with the enzyme with compounds 87-93, is depicted on Table 4[118-122].<smiles>[R]C1C=C2CCC3C4CC[C@H](C5CN5)[C@]4(C)CC[C@H]3[C@]2(C)CC1</smiles>

$\mathrm{R}=\beta-\mathrm{OH} ; \Delta_{5}^{5} ; 20 \mathrm{~S}$ $\mathrm{R}=\beta-\mathrm{OH} ; \Delta^{5} ; 20 R \quad 79$ $\mathrm{R}=\mathrm{O} ; \Delta^{4} ; 20 S \quad 80$ $\mathrm{R}=\mathrm{O} ; \Delta^{4} ; 20 R$<smiles>C=C1CC2C(CC[C@]3(C)C(C(C)=O)CCC23)C2(C)CCC(=O)C=C12</smiles>

85

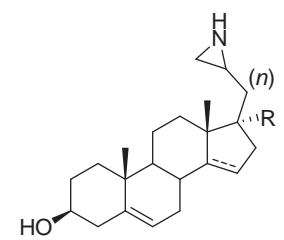

$\mathrm{R}=\mathrm{H} ; \Delta^{14} ; n=0 ; 20 R \quad 82$ $\mathrm{R}=\mathrm{H} ; \Delta^{14} ; n=0 ; 20 S \quad 83$ $\mathrm{R}=\mathrm{H} ; n=1 ;(21 S, 21 R) 1: 1 \quad \mathbf{8 4}$<smiles></smiles>

86

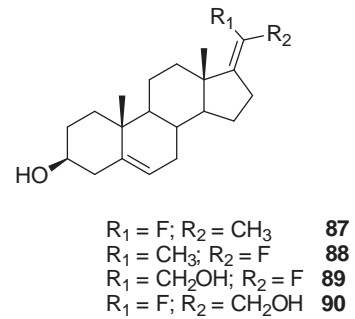

$\begin{array}{ll}\mathrm{R}_{1}=\mathrm{CH}_{3} ; \mathrm{R}_{2}=\mathrm{F} & 88 \\ \mathrm{R}_{1}=\mathrm{CH}_{2} \mathrm{OH} ; \mathrm{R}_{2}=\mathrm{F} & \mathbf{8 9} \\ \mathrm{R}_{1}=\mathrm{F} ; \mathrm{R}_{2}=\mathrm{CH}_{2} \mathrm{OH} & 90\end{array}$<smiles>C/C(=C1\C(=O)CC2C3CC=C4C[C@@H](OC(C)(C)C)CC[C@]4(C)C3CC[C@@]12C)C(F)F</smiles>

91<smiles>[R]C(Br)=C(C)C1=CCC2C3CC=C4C[C@@H](O)CC[C@]4(C)C3CC[C@]12C</smiles>

$\mathrm{R}_{1}=\mathrm{R}_{2}=\mathrm{H} \quad 92$
$\mathrm{R}_{1}=\mathrm{R}_{2}=\mathrm{F} ; \Delta^{16} 93$

Figure 7. Pregnane based CYP17 inhibitors. 


\begin{tabular}{cccc}
\hline Entry & Compound & \% Inhibition & Ref. \\
\hline 1 & 87 & 61 & [119-121] \\
\hline 2 & 88 & 60 & \\
\hline 3 & 89 & 61 & \\
\hline 4 & 90 & 94 & {$[122]$} \\
\hline 5 & 91 & 85 \\
\hline 7 & 92 & 60 \\
\hline 9 & 93 & 62 \\
\hline
\end{tabular}

Table 4. Inhibition of cynomolgous monkey testicular CYP17 by pregnane derivatives, at $1 \mu \mathrm{M}$, following preincubation with enzyme.

\subsection{Other steroidal inhibitors}

Other reported steroidal inhibitors of CYP17 are depicted on figure 8. The 17-aza derivative 94 inhibited human CYP17 with an $\mathrm{IC}_{50}$ value of $4.9 \mu \mathrm{M}$ [123]. Compound 95 inhibited both $5 \alpha$-reductase and CYP17 with $\mathrm{k}_{\mathrm{i}}$ values of 27 and $14 \mathrm{nM}$, respectively [124]. The oxime 96 was also a dual inhibitor with the ability to reduce serum and prostatic T and DHT concentrations in vivo [125].<smiles>CC(=O)N1CCCC2C3CC=C4C[C@@H](O)CC[C@]4(C)C3CC[C@]21C</smiles>

94<smiles>C[C@H](CO)[C@H]1CCC2C3CCC4=C(N)C(=O)CC[C@]4(C)C3CC[C@]21C</smiles>

95<smiles>CC(C(=O)O)[C@H]1CCC2C3CCC4=CC(=O)CC[C@]4(C)C3CC[C@]21C</smiles>

96

Figure 8. Other steroidal inhibitors of CYP17. 


\section{Abiraterone and galeterone}

As previously mentioned, abiraterone acetate 3 (Fig. 1) constitutes the first and still the only steroidal CYP17 inhibitor approved by the FDA in 2011, being indicated for the treatment of mCRPC after chemotherapy [14].

This drug was developed at the Institute of Cancer Research (UK) considering the known efficacy and limitations of ketoconazole in this field and following the observation that nonsteroidal 3-pyridyl esters had improved selectivity for the inhibition of CYP17. This led to the preparation of abiraterone 21 (Fig. 4), a $\Delta^{5,16}$-steroid with a 3-pyridyl group bound to $\mathrm{C} 17$, which revealed to be a potent and selective irreversible inhibitor of both $17 \alpha$-hydroxylase and $\mathrm{C}_{17,20}$-lyase activities of CYP17 [86, 126, 127]. In fact, it was observed that abiraterone 21 is not only a more potent CYP17 inhibitor than ketoconazole but also is a less effective inhibitor of other CYP450 enzymes, responsible for the significant side effects and potential pharmacological interactions of ketoconazole in PC therapy [14, 128]. Accordingly, preclinical studies in mice demonstrated that abiraterone 21 reduced serumT to castrate levels, in spite of a compensatory significant increase in luteinizing hormone (LH) [126]. However, when abiraterone acetate 3was tested in human PC patients for the first time as a substitute to gonadotropin-releasing hormone $(\mathrm{GnRH})$ analogues, sustained suppression of $\mathrm{T}$ production was not observed due to an increase in LH levels [129]. For this reason, abiraterone 21was developed to be concomitantly used with GnRH analogues in mCRPC [130]. Studies in xenograft models devoid of testicular and adrenal androgens further evidenced that abiraterone 21 inhibited CRPC growth and thus also seem to suppress androgen production in PC tumors [128].

Several Phase I clinical studies [131, 132] revealed that abiraterone acetate 3 is safe and effective on lowering serum androgen levels in both ketoconazole naïve and exposed patients. In addition, its antitumor activity was nearly equivalent in both groups. However, a significant increase in adrenocorticotrophic hormone (ACTH) was developed leading to hypokalemia and hypertension as the predominant toxicities. In order to reduce these side effects eplerenone, a mineralocorticoid antagonist, was introduced. As the highest studied dosage of abiraterone acetate $3(1000 \mathrm{mg})$ did not lead to limiting toxicities, the useof $1000 \mathrm{mg}$ daily was chosen in additional trials [8, 131, 133 135].

The concomitant use of the corticosteroids dexamethasone or prednisone in the efficacy of abiraterone acetate 3in several conditions was studied in Phase II trials [133-135]. A significant decrease in hyperaldosteronism-related symptoms was observed and therefore prednisone $5 \mathrm{mg}$ b.i.d. was included in all subsequent studies, as well as in the FDA label indication. Other Phase II studies evaluated the efficacy of abiraterone in docetaxel-treated CRPC patients, and continued to evidence the importance of this steroidal drug in this stage of the pathology [135].

A Phase III study compared the use of abiraterone acetate 3and prednisone versus prednisone alone in 1195 ketoconazole-naïve men with mCRPCshowing disease progression dur- 
ing or after therapy withdocetaxel. The primary endpoint was overall survival and the secondary endpoints were PSA decline, time to PSA progression and progression-free survival. In this study an increased median overall survival in the abiraterone acetate $3+$ predisone group was observed when compared to that of patients treated with prednisone alone (14.8 vs 10.9 months; hazard ratio of 0.65 ). In addition, all the other endpoints were met and as expected the toxicities caused by CYP17 blockage occurred mostly in the abiraterone acetate 3+ prednisone group. Another Phase III study set to be completed in 2014 is evaluating the use of abiraterone acetate 3 and prednisone versus prednisone alone in CRPC prior to chemotherapy [136].

Due to all these beneficial results and after the first Phase III studies, in April 2011, abiraterone acetate 3 was approved by the FDA for the treatment of mCRPC after chemotherapy [14].

Abiraterone 3 is being used in the form of its $3 \beta$-acetyl prodrug in order to increase its oral bioavailability, and is quickly deacetylated to the active drug once absorbed. In spite of the fact that high-fat meals increase its oral absorption, it is recommended that this drug should be taken on an empty stomach. Other pharmacokinetic studies revealed that this drug is highly bound to plasma proteins and has a plasma half-life of 10-14h [131, 132]. At present, several other clinical trials are ongoing, mainly for the study of the combination of abiraterone acetate 3 with other relevant drugs in PC treatment [137].

Galeterone 4 (Fig. 1) is structurally similar to abiraterone 21 and was rationally designed as an androgen biosynthesis inhibitor via CYP17 inhibition [8]. In fact, as previously mentioned, several research works evidenced that modification of the C17 substituent of $\Delta^{16}$-steroids, particularly by attachment of nitrogen heterocycles, was a relevant strategy to produce potent inhibitors of the enzyme. Following these considerations, Handratta et al. designed and prepared several $\Delta^{16}$-steroidal $\mathrm{C} 17$ benzoazoles and pyrazines and evaluated their CYP17 and 5 $\alpha$-reductase inhibitory activities, binding to and transactivation of the AR, as well as their antiproliferative effects against two human PC cell lines (LNCaP and LAPC4). Some of the compounds including 4 and its $\Delta^{4}$-3-ketone derivative 56 (Fig. 5) were potent CYP17 inhibitors and antagonists of both wild type and mutant AR. These compounds were the first reported examplesbearing such a dual activity. In addition, these steroids inhibited the growth of DHT-stimulated LNCaP and LACP4 PC cells with $\mathrm{IC}_{50}$ values in the low micromolar range. Galeterone 4 and compound 56 were further studied for pharmacokinetic properties and antitumor activities against androgen-dependent LAPC4 human prostate tumor xenografts in severe combined immunodeficient (SCID) mice. Galeterone 4 was more effective than castration in its in vivo antitumor activity [104]. Taking this into account, Vasaitis et al. demonstrated by in vitro and in vivo studies that unlike bicalutamide and castration, galeterone 4 also caused down-regulation of AR protein expression, which appears to contribute to its antitumor efficacy. The authors also evidenced that this compound caused a significant regression of LAPC4 tumors in xenograft models, being more 
potent than castration, and that treatment with galeterone 4 was also very effective in preventing the formation of LAPC4 tumors [138].

An in vitro study using high-passage LNCaP cells demonstrated that galeterone 4 inhibited the proliferation of these cells that were no longer sensitive to bicalutamide and had increased AR expression. In addition, the combination of galeterone 4with inhibitors of signal transduction pathways such as gefitinib and everolimus, was proven to be synergistic when compared to either agent alone and superior to their combination with bicalutamide [139]. Later, in vivo studies with LNCaP and high-passage LNCaP tumor xenografts in SCID mice indicated that dual inhibition of AR and mammalian target of rapamycin (mTOR) in castration-resistant models can restore the sensitivity of tumours to anti-androgen therapy. The results observed in this study also indicated that the CYP17 and AR inhibitor galeterone 4 combined with the mTOR inhibitor everolimus may be effective in resistant PC [140].

A very recent in vitro study with $\mathrm{LNCaP}$ and LAPC4 cells demonstrated that both galeterone 4 and abiraterone 21 directly down-regulated the expression and activation of the AR via multiple mechanisms, in addition to their CYP17 inhibitory activities [141].

Due to the impressive biological activities observed, galeterone 4 is currently being evaluated in a phase I/II open label clinical trial (ARMOR1 study) as a potential drug for the treatment of castration resistant prostate cancer. This study began in 2009 and has as primary outcomes the incidence of adverse effects (phase I) and the proportion of patients with $50 \%$ or greater decrease in PSA from baseline (phase II) [137].

Recently, in a continuing study of the clinical candidate 4 and analogues as potential agents for PC treatment, putative metabolites of 4 and metabolically stable derivatives were prepared. Putative metabolites included compounds with no double bonds at C16, C5, or both as well as their corresponding 3-oxo derivatives. Metabolically stable analogues of 4 , developed to optimize its potency and to increase its stability and oral bioavailability, included their $3 \alpha$-azido, $3 \xi$-fluoro, $3 \beta$-mesylate and $3 \beta$-O-sulfamoyl derivatives. Several in vitro studies, including CYP17 inhibitory activity, binding to and transactivation of AR, as well as antiproliferative effects against LNCaP and LAPC4 cell lines, demonstrated that none of the compounds were superior to 4 in the observed effects. The 3 -fluoro analogue was, however, nearly 2 -fold more efficacious vs LAPC4 xenografts than 4 . Nonetheless, the toxicity observed with this halogenated compound was of concern [142].

\section{Conclusion}

PC is one of the most prevalent causes of death in Europe and USA. In spite of important advances in the treatment of localized disease, advanced PC is still incurable. One of the most relevant PC therapeutic strategies involves the inhibition of androgen biosynthesis by 
CYP17 inhibition. In fact, starting from the structure of the natural substrates of this enzyme, several steroids, mainly with a heterocyclic ring bound to $\mathrm{C} 17$, have been developed over the years as CYP17 inhibitors. All these studies successfully led to the approval of abiraterone acetate 3 by the FDA in 2011 for the treatment of mCRPC after chemotherapy. In addition, other clinical trials involving this drug are being performed in order to expand its clinical usefulness, namely in CRPC prior to chemotherapy and in combination with other drugs. Another steroid that is in Phase I/II clinical trials for CRPC is galeterone 4, which is structurally similar to abiraterone 21 . However, in addition to bearing a potent and selective CYP17 inhibitory activity, this compound also modulates AR activity. As it is now clear that function of the AR axis remains crucial to a majority of patients with CRPC, its mechanism of action can be of great advantage in PC therapy, either alone or in combination with other AR-modulating agents.In the future it is expected that the invaluable knowledge provided by the use of CYP17 inhibitors in PC treatment will shed more light on the most significant biological pathways involved in this disease. The establishment of a possible role for combination regimens including CYP17 inhibitors in earlier stages of PC as a means to prevent surgery and classical chemotherapy drugs would undoubtedly contribute to improving the quality of life of PC patients.

\section{Acknowledgments}

Jorge A. R. Salvador thanks Universidade de Coimbra and Centro de Neurociências e Biologia Celular for financial support. Vânia M. Moreira acknowledges Fundação para a Ciência e a Tecnologia for financial support (SFRH/BPD/45037/2008).

\section{Author details}

Jorge A. R. Salvador ${ }^{1,2}$, Vânia M. Moreira ${ }^{3}$ and Samuel M. Silvestre ${ }^{4}$

*Address all correspondence to: salvador@ci.uc.pt

1 Laboratório de Química Farmacêutica, Faculdade de Farmácia, Universidade de Coimbra,Pólo das Ciências da Saúde, Azinhaga de Santa Comba, Coimbra, Portugal

2 Centro de Neurociências e Biologia Celular, Universidade de Coimbra, Coimbra, Portugal

3 Division of Pharmaceutical Chemistry, Faculty of Pharmacy, Viikinkaari, University of Helsinki, Helsinki, Finland

4 Health Sciences Research Centre, Faculdade de Ciências da Saúde,Universidade da Beira Interior,Covilhã, Portugal 


\section{References}

[1] Jordan V C and Brodie A M H. Development and evolution of therapies targeted to the estrogen receptor for the treatment and prevention of breast cancer. Steroids 2007;72(1): 7-25.

[2] Brodie A, Njar V, Macedo L F, Vasaitis T S and Sabnis G. The Coffey Lecture: Steroidogenic enzyme inhibitors and hormone dependent cancer. Urologic Oncology: Seminars and Original Investigations 2009;27(1): 53-63.

[3] Moreira V M, Salvador J A R, Vasaitis T S and Njar V C. CYP17 Inhibitors for Prostate Cancer Treatment - An Update. Current Medicinal Chemistry 2008;15(9): 868-899.

[4] Moreira V M A, Vasaitis T S, Guo Z, Njar V C O and Salvador J A R. Synthesis of Novel C17 Steroidal Carbamates. Studies on CYP17 Action, Androgen Receptor Binding and Function, and Prostate Cancer Cell Growth. Steroids 2008;73(12): 1217-1227.

[5] Moreira V M A, Vasaitis T S, Njar V C O, and Salvador J A R. Synthesis and evaluation of novel 17-indazole androstene derivatives designed as CYP17 inhibitors. Steroids 2007;72(14): 939-948.

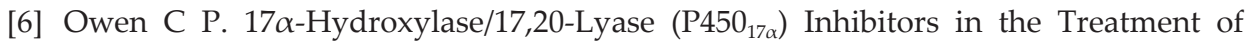
Prostate Cancer: A Review. Anti-Cancer Agents in Medicinal Chemistry 2009;9(6): 613-626.

[7] Pezaro C J, Mukherji D and De Bono J S. Abiraterone acetate: redefining hormone treatment for advanced prostate cancer. Drug Discovery Today 2012;17(5-6): 221-226.

[8] Vasaitis T S, Bruno R D and Njar V C O. CYP17 inhibitors for prostate cancer therapy. Journal of Steroid Biochemistry and Molecular Biology 2011;125(1-2): 23-31.

[9] Ang J E, Olmos D and Bono J S. CYP17 blockade by abiraterone: further evidence for frequent continued hormone-dependence in castration-resistant prostate cancer. British Journal of Cancer 2009;100(5): 671-675.

[10] Mancuso A, Oudard S and Sternberg C N. Effective chemotherapy for hormone-refractory prostate cancer (HRPC): Present status and perspectives with taxane-based treatments. Critical Reviews in Oncology/Hematology 2007;61(2): 176-185.

[11] Harzstark A L and Small E J. Castrate-resistant prostate cancer: therapeutic strategies. Expert Opinion on Pharmacotherapy 2010;11(6): 937-945.

[12] Sartor A O. Progression of metastatic castrate-resistant prostate cancer: impact of therapeutic intervention in the post-docetaxel space. Journal of Hematology \& Oncology 2011;4: 18.

[13] Logothetis C J, Efstathiou E, Manuguid F and Kirkpatrick P. Abiraterone acetate. Nature Reviews Drug Discovery 2011;10: 573-574. 
[14] Bryce A and Ryan C J. Development and Clinical Utility of Abiraterone Acetate as an Androgen Synthesis Inhibitor. Clinical Pharmacology \& Therapeutics 2012;91(1): 101-108.

[15] Vasaitis T S and Njar V C O. Novel, potent anti-androgens of therapeutic potential: recent advances and promising developments. Future Medicinal Chemistry 2010;2(4): 667-680.

[16] Molina A and Belldegrun A. Novel Therapeutic Strategies for Castration Resistant Prostate Cancer: Inhibition of Persistent Androgen Production and Androgen Receptor Mediated Signaling. Journal of Urology 2011;185(3): 787-794.

[17] Jarman M, Smith H J, Nicholls P J and Simons C. Inhibitors of Enzymes of Androgen Biosynthesis: Cytochrome P450 $17 \alpha$ and $5 \alpha$-Steroid Reductase. Natural Product Reports 1998;15(5): 495-512.

[18] Baston E and Leroux F. Inhibitors of Steroidal Cytochrome P450 Enzymes as Targets For Drug Development. Recent Patents on Anti-cancer Drug Discovery 2007;2(1): 31-58.

[19] Hartmann R W, Ehmer P B, Haidar S, Hector M, Jose J, Klein C D, Seidel S B, Sergejew T F, Wachall B G, Wächter G A, and Zhuang Y. Inhibition of CYP 17, a New Strategy for the Treatment of Prostate Cancer. Archiv der Pharmazie (Weinheim) 2002;335(4): 119-128.

[20] Schneider G and Wolfling J. Synthetic Cardenolides and Related Compounds. Current Organic Chemistry 2004;8(14): 1381-1403.

[21] Haider S M, Patel J S, Poojari C S, and Neidle S. Molecular Modeling on Inhibitor Complexes and Active-Site Dynamics of Cytochrome P450 C17, a Target for Prostate Cancer Therapy. Journal of Molecular Biology 2010;400(5): 1078-1098.

[22] DeVore N M and Scott E E. Structures of cytochrome P450 17A1 with prostate cancer drugs abiraterone and TOK-001. Nature 2012;482: 116-119.

[23] Nakajin S, Hall P F and Onoda M. Testicular Microsomal Cytochrome P-450 for $C_{21}$ Steroid Side Chain Cleavage. Spectral and Binding Studies. Journal of Biological Chemistry 1981;256(12): 6134-6139.

[24] Nakajin S and Hall P F. Microsomal Cytochrome P-450 from Neonatal Pig Testis. Purification and Properties of a $\mathrm{C}_{21}$ Steroid Side-chain Cleavage System (17 $\alpha$-hydroxylase- $C_{17,20}$ lyase). Journal of Biological Chemistry 1981;256(8): 3871-3876.

[25] Nakajin S, Shively J E, Yuan P M and Hall P F. Microsomal Cytochrome P-450 from Neonatal Pig Testis: Two Enzymatic Activities (17 $\alpha$-Hydroxylase and $\mathrm{C}_{17,20}$-Lyase) Associated with One Protein. Biochemistry 1981;20(14): 4037-4042.

[26] Zuber M X, Simpson E R and Waterman M R. Expression of Bovine $17 \alpha$-Hydroxylase Cytochrome P-450 cDNA in Nonsteroidogenic (COS 1) Cells. Science 1986;234(4781): 1258-1261. 
[27] Onoda M, Haniu M, Yanagibashi K, Sweet F, Shively J E and Hall P F. Affinity Alkylation of the Active Site of $\mathrm{C}_{21}$ Steroid Side-chain Cleavage Cytochrome P-450 from Neonatal Porcine Testis: a Unique Cysteine Residue Alkylated by 17-(Bromoacetoxy)progesterone. Biochemistry 1987;26(2): 657-662.

[28] Hall P F. Cytochrome P-450 $C_{21 s c c}$ : One Enzyme with Two Actions: Hydroxylase and Lyase. Journal of Steroid Biochemistry and Molecular Biology 1991;40(4-6): 527-532.

[29] Meunier B, Visser S P and Shaik S. Mechanism of Oxidation Reactions Catalyzed by Cytochrome P450 Enzymes. Chemical Reviews 2004;104(9): 3947-3980.

[30] Denisov I G, Makris T M, Sligar S G and Schlichting I. Structure and Chemistry of Cytochrome P450. Chemical Reviews 2005;105(6): 2253-2277.

[31] Gao W, Bohl C E and Dalton J T. Chemistry and Structural Biology of Androgen Receptor. Chemical Reviews 2005;105(9): 3352-3370.

[32] Guyton A C and Hall J E. Textbook of Medical Physiology. Philadelphia: WB Saunders Company; 2000.

[33] Koivisto P, Kolmer M, Visakorpi T and Kallioniemi O P. Androgen Receptor Gene and Hormonal Therapy Failure of Prostate Cancer. American Journal of Pathology 1998;152(1): 1-9.

[34] Isaacs J T and Isaacs W B. Androgen Receptor Outwits Prostate Cancer Drugs. Nature Medicine 2004;10(1): 26-27.

[35] Chatterjee B. The Role of the Androgen Receptor in the Development of Prostatic Hyperplasia and Prostate Cancer. Molecular and Cellular Biochemistry 2003;253(1-2): 89-101.

[36] Huggins C and Hodges C V. Studies on Prostatic Cancer. I. The Effect of Castration, of Estrogen and of Androgen Injection on Serum Phosphatases in Metastatic Carcinoma of the Prostate. Cancer Research 1941;1: 293-297.

[37] Huggins C, Stevens R E and Hodges C V. Studies on Prostatic Cancer. II. The Effect of Castration on Clinical Patients with Carcinoma of the Prostate. Archives of Surgery 1941;43: 209-223.

[38] Denis L J and Griffiths K. Endocrine Treatment in Prostate Cancer. Seminars in Surgical Oncology 2000;18(1): 52-74.

[39] Chung B C, Picado-Leonard J, Haniu M, Bienkowski M, Hall P F, Shively J E and Miller W L. Cytochrome P450c17 (Steroid 17 $\alpha$-Hydroxylase/17,20 Lyase): Cloning of Human Adrenal and Testis cDNAs Indicates the Same Gene is Expressed in Both Tissues. Proceedings of the National Academy of Sciences of the United States of America 1987;84(2): 407-411.

[40] Sparkes R S, Klisak I and Miller W L. Regional Mapping of Genes Encoding Human Steroidogenic Enzymes: P450 scc to 15q23-q24, Adrenodoxin to 11q22; Adrenodoxin 
Reductase to 17q24-q25; and P450c17 to 10q24-q25.DNA and Cell Biology 1991;10(5): 359-365.

[41] Fan Y S, Sasi R, Lee C, Winter J S, Waterman M R and Lin C C. Localization of the Human CYP17 gene (cytochrome $\mathrm{P} 50_{17 \alpha}$ ) to $10 \mathrm{q} 24.3$ by Fluorescence in situ Hybridization and Simultaneous Chromosome Banding. Genomics 1992;14(4): 1110-1111.

[42] Yanagibashi K and Hall P F. Role of Electron Transport in the Regulation of the Lyase Activity of C21 Side-chain Cleavage P-450 From Porcine Adrenal and Testicular Microsomes. Journal of Biological Chemistry 1986;261(18): 8429-8433.

[43] Lin D, Black S M, Nagahama Y and Miller W L. Steroid 17 $\alpha$-Hydroxylase and 17,20Lyase Activities of P450c17: Contributions of Serine106 and P450 Reductase. Endocrinology 1993;132(6): 2498-2506.

[44] Pandey A V and Miller W L. Regulation of 17,20-Lyase Activity by Cytochrome $b_{5}$ and by Serine Phosphorylation of P450c17. Journal of Biological Chemistry 2005;280(14): 13265-13271.

[45] Dharia S, Slane A, Jian M, Conner M, Conley A J and Parker C R. Colocalization of P450c17 and Cytochrome $b_{5}$ in Androgen-synthesizing Tissues of the Human. Biology of the Reproduction 2004;71(1): 83-88.

[46] Akhtar M K, Kelly S L, and Kaderbhai M A. Cytochrome $b_{5}$ Modulation of $17 \alpha-\mathrm{Hy}-$ droxylase and 17,20-lyase (CYP17) Activities in Steroidogenesis. Journal of Endocrinology 2005;187(2): 267-274.

[47] Naffin-Olivos J L and Auchus R J. Human Cytochrome $b_{5}$ Requires Residues E48 and E49 to Stimulate the 17,20-Lyase Activity of Cytochrome P450c17. Biochemistry 2006;45(3): 755-762.

[48] Akhtar M, Wright J N and Lee-Robichaud P. A review of mechanistic studies on aromatase (CYP19) and 17 $\alpha$-hydroxylase-17,20-lyase (CYP17). Journal of Steroid Biochemistry and Molecular Biology 2011;125(1-2): 2-12.

[49] Zhang L H, Rodriguez H, Ohno S and Miller W L. Serine Phosphorylation of Human P450c17 Increases 17,20-Lyase Activity: Implications for Adrenarche and the Polycystic Ovary Syndrome. Proceedings of the National Academy of Sciences of the United States of America 1995;92(23): 10619-10623.

[50] Pandey A V, Mellon S H and Miller W L. Protein Phosphatase 2A and Phosphoprotein SET Regulate Androgen Production by P450c17. Journal of Biological Chemistry 2003;278(5): 2837-2844.

[51] Souter I, Munir I, Mallick P, Weitsman S R, Geller D H and Magoffin D A. Mutagenesis of Putative Serine-threonine Phosphorylation Sites Proximal to Arg255 of Human Cytochrome P450c17 Does Not Selectively Promote Its 17,20-Lyase Activity.Fertility and Sterility 2006;85: 1290-1299. 
[52] Geller D H, Auchus R J, Mendonca B B and Miller W L. The Genetic and Functional Basis of Isolated 17,20-Lyase Deficiency. Nature Genetics 1997;17(2): 201-205.

[53] Lee-Robichaud P, Akhtar M E and Akhtar M. Lysine Mutagenesis Identifies Cationic Charges of Human CYP17 That Interact With Cytochrome $b_{5}$ to Promote Male Sexhormone Biosynthesis. Biochemical Journal 1999;342: 309-312.

[54] Van Den Akker E L, Koper J W, Boehmer A L, Themmen A P, Verhoef-Post M, Timmerman M A, Otten B J, Drop S L and De Jong F H. Differential Inhibition of $17 \alpha-$ Hydroxylase and 17,20-Lyase Activities by Three Novel Missense CYP17 Mutations Identified in Patients With P450c17 Deficiency. Journal of Clinical Endocrinology \& Metabolism 2002;87(12): 5714-5721.

[55] Sherbet D P, Tiosano D, Kwist K M, Hochberg Z and Auchus R J. CYP17 Mutation E305G Causes Isolated 17,20-Lyase Deficiency by Selectively Altering Substrate Binding. Journal of Biological Chemistry 2003;278(49): 48563-48569.

[56] Miller W L, Auchus R J and Geller D H. The Regulation of 17,20-Lyase Activity. Steroids 1997;62(1): 133-142.

[57] Laughton C A, Neidle S, Zvelebil M J and Sternberg M J. A Molecular Model for The Enzyme Cytochrome P450 $17 \alpha$, a Major Target for The Chemotherapy of Prostatic Cancer.Biochemical and Biophysical Research Communications 1990;171(3): 1160-1167.

[58] Lin D, Zhang L H, Chiao E and Miller W L. Modeling and Mutagenesis of the Active Site of Human P450c17. Molecular Endocrinology 1994;8(3): 392-402.

[59] Burke D F, Laughton C A and Neidle S. Homology Modelling of the Enzyme P450 17 $\alpha$-Hydroxylase/17,20-Lyase - A Target For Prostate Cancer Chemotherapy - From the Crystal Structure of P450BM-3. Anticancer Drug Design 1997;12(2): 113-123.

[60] Lewis D F and Lee-Robichaud P. Molecular Modelling of Steroidogenic Cytochromes P450 From Families CYP11, CYP17, CYP19 and CYP21 Based on the CYP102 Crystal Structure. Journal of Steroid Biochemistry and Molecular Biology 1998;66(4): 217-233.

[61] Auchus R J and Miller W L. Molecular Modeling of Human P450c17 (17 $\alpha$-Hydroxylase/17,20-Lyase): Insights into Reaction Mechanisms and Effects of Mutations. Molecular Endocrinology 1999;13(7): 1169-1182.

[62] Schappach A and Holtje H D. Molecular Modelling of 17 $\alpha$-Hydroxylase-17,20-Lyase. Pharmazie 2001;56(6): 435-442.

[63] Yang J, Cui B, Sun S, Shi T, Zheng S, Bi Y, Liu J, Zhao Y, Chen J, Ning G and Li X. Phenotype-genotype correlation in eight Chinese $17 \alpha$-hydroxylase/17,20 lyase-deficiency patients with five novel mutations of CYP17A1 gene. Journal of Clinical Endocrinology \& Metabolism 2006;91(9): 3619-3625.

[64] Mendieta M A E P B, Negri M, Jagusch C, Muller-Vieira U, Lauterbach T and Hartmann R W. Synthesis, biological evaluation, and molecular modeling of abiraterone 
analogues: novel CYP17 inhibitors for the treatment of prostate cancer. Journal of Medicinal Chemistry 2008;51(16): 5009-5018.

[65] Swart A C, Storbeck K H and Swart P. A single amino acid residue, Ala 105, confers $16 \alpha$-hydroxylase activity to human cytochrome P450 17 $\alpha$-hydroxylase/17,20 lyase. Journal of Steroid Biochemistry and Molecular Biology 2010;119(3-5): 112-120.

[66] Wang J F, Zhang C C, Chou K C and Wei D Q. Structure of cytochrome P450s and personalized drug. Current Medicinal Chemistry 2009;16(2): 232-244.

[67] Moncada B and Baranda L. Ketoconazole and gynecomastia. Journal of the American Academy of Dermatology 1982;7(4): 557-558.

[68] Pont A, Williams P L, Azhar S, Reitz R E, Bochra C, Smith E R and Stevens D A. Ketoconazole Blocks Testosterone Synthesis. Archives of Internal Medicine 1982;142(12): 2137-2140.

[69] De Felice R, Johnson D G and Galgiani J N. Gynecomastia With Ketoconazole. Antimicrobial Agents and Chemotherapy 1981;19(6): 1073-1074.

[70] Heeres J, Backx L J, Mostmans J H and Cutsem J V. Antimycotic Imidazoles. Part 4. Synthesis and Antifungal Activity of Ketoconazole, a New Potent Orally Active Broad-spectrum Antifungal Agent. Journal of Medicinal Chemistry 1979;22(8): 1003-1005.

[71] Moffat L E, Kirk D, Tolley D A, Smith M F and Beastall G. Ketoconazole as Primary Treatment of Prostatic Cancer. British Journal of Urology 1988;61(5): 439-440.

[72] Mahler C, Verhelst J and Denis L. Ketoconazole and Liarozole in the Treatment of Advanced Prostatic Cancer. Cancer 1993;71(3 Suppl): 1068-1073.

[73] Lake-Bakaar G, Scheuer P J and Sherlock S. Hepatic Reactions Associated With Ketoconazole in the United Kingdom. British Medical Journal 1987;294: 419-422.

[74] Schappach A and Holtje H D. Investigations on Inhibitors of Human 17 $\alpha$-Hydroxylase-17,20-Lyase and Their Interactions With the Enzyme. Molecular Modelling of 17 $\alpha$-Hydroxylase-17,20-Lyase, Part II. Pharmazie 2001;56(11): 835-842.

[75] Arth G E, Patchett A A, Jefopoulus T, Bugianesi R L, Peterson L H, Ham E A, Kuehl F A and Brink N G. Steroidal Androgen Biosynthesis Inhibitors. Journal of Medicinal Chemistry 1971;14(8): 675-679.

[76] Nakajin S, Takahashi K and Shinoda M. Inhibitory Effect and Interaction of Stanozolol With Pig Testicular Cytochrome P-450 (17 $\alpha$-hydroxylase/ $\mathrm{C}_{17,20}$-lyase). Chemical \& Pharmaceutical Bulletin (Tokyo) 1989;37(7): 1855-1858.

[77] Angelastro M R, Laughlin M E, Schatzman G L, Bey P and Blohm T R. 17ß-(Cyclopropylamino)-androst-5-en-3 $\beta$-ol, A Selective Mechanism-based Inhibitor of Cyto-

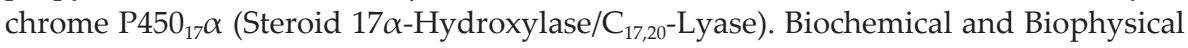
Research Communications 1989;162(3): 1571-1577. 
[78] Angelastro M R and Blohm T R. 4-Substituted 17 $\beta$-(cyclopropyloxy)androst-5-en-3 $\beta$ ol and Related Compounds Useful as $C_{17,20}$-Lyase Inhibitors. US Patent 4,966,897; 1990.

[79] Angelastro M R, Marquart A L, Weintraub P M, Gates C A, Laughlin M E, Blohm T R and Peet N P. Time-dependent Inactivation of Steroid $\mathrm{C}_{17(20)}$-Lyase by $17 \beta$-Cyclopropyl Ether-substituted Steroids. Bioorganic \& Medicinal Chemistry Letters 1996;6(1): 97-100.

[80] Weintraub P M, Gates C, Angelastro M R and Flynn G A. Process For the Preparation of 4-Amino- $\Delta^{4}$-3-ketosteroids Via Nitro- $\Delta^{4}$-3-ketosteroids. WO Patent 95/29932; 1995.

[81] Weintraub P M, Gates C A, Angelastro M R, Curran T T and Johnston J O. 4-Amino-17 $\beta$ - (Cyclopropyloxy)androst-4-en-3-one, 4-Amino-17 $\beta$-(Cyclopropylamino)androst-4-en-3-one and Related Compounds as $\mathrm{C}_{17,20}$-Lyase and $5 \alpha$-Reductase Inhibitors. US Patent 5,486,511; 1996.

[82] Wilson S R and Miao E. Anti-testosterone compounds and Method of Use Thereof. WO Patent 92/15604; 1992.

[83] Burkhart J P, Gates C A, Laughlin M E, Resvick R J and Peet N P. Inhibition of Steroid $\mathrm{C}_{17(20)}$-Lyase With C17-Heteroaryl Steroids. Bioorganic \& Medicinal Chemistry 1996;4(9): 1411-1420.

[84] Peet N P, Burkhart J P and Gates C. 16-Unsaturated C17 Heterocyclic Steroids Useful as Steroid $C_{17,20}$-Lyase Inhibitors. US Patent 5,677,293; 1997.

[85] Peet N P, Burkhart J P and Gates C. Methods and Compositions using $\Delta^{16}$-Unsaturated C17-Heterocyclic Steroids Useful as $C_{17,20}$-Lyase Inhibitors. US Patent 5,977,094; 1999.

[86] Potter G A, Barrie S E, Jarman M and Rowlands M G. Novel Steroidal Inhibitors of Human Cytochrome P450 $17 \alpha$ (17 $\alpha$-Hydroxylase- $\mathrm{C}_{17,20}$-Lyase): Potential Agents For the Treatment of Prostatic Cancer. Journal of Medicinal Chemistry 1995;38(13): 2463-2471.

[87] Haidar S, Ehmer P B and Hartmann R W. Novel Steroidal Pyrimidyl Inhibitors of P450 17 (17 $\alpha$-Hydroxylase/ $\mathrm{C}_{17,20}$-Lyase). Archiv der Pharmazie (Weinheim) 2001;334(12): 373-374.

[88] Haidar S, Ehmer P B, Barassin S, Batzl-Hartmann C and Hartmann R W. Effects of Novel $17 \alpha$-Hydroxylase/ $\mathrm{C}_{17,20}$-Lyase (P450 17, CYP 17) Inhibitors on Androgen Biosynthesis in vitro and in vivo. Journal of Steroid Biochemistry and Molecular Biology 2003;84(5): 555-562.

[89] Ling Y Z, Li J S, Liu Y, Kato K, Klus G T and Brodie A. 17-Imidazolyl, Pyrazolyl, and Isoxazolyl Androstene Derivatives. Novel Steroidal Inhibitors of Human Cytochrome $\mathrm{C}_{17,20}$-Lyase (P450 ${ }_{17 \alpha}$ ). Journal of Medicinal Chemistry 1997;40(20): 3297-3304.

[90] Brodie A and Yangzhi L. Androgen Synthesis Inhibitors. US Patent 6,133,280; 2000. 
[91] Nnane I P, Kato K, Liu Y, Lu Q, Wang X, Ling Y Z and Brodie A. Effects of Some Novel Inhibitors of $C_{17,20}$-Lyase and $5 \alpha$-Reductase in vitro and in vivo and Their Potential Role in the Treatment of Prostate Cancer. Cancer Research 1998;58(17): 3826-3832.

[92] Klus G T, Nakamura J, Li J S, Ling Y Z, Son C, Kemppainen J A, Wilson E M and Brodie A M. Growth Inhibition of Human Prostate Cells in vitro by Novel Inhibitors of Androgen Synthesis. Cancer Research 1996;56(21): 4956-4964.

[93] Long B J, Grigoryev D N, Nnane I P, Liu Y, Ling Y Z and Brodie A M. Antiandrogenic Effects of Novel Androgen Synthesis Inhibitors on Hormone-dependent Prostate Cancer. Cancer Research 2000;60(23): 6630-6640.

[94] Nnane I P, Long B J, Ling Y Z, Grigoryev D N and Brodie A M. Anti-tumour Effects and Pharmacokinetic Profile of 17-(5'-Isoxazolyl)androsta-4,16-dien-3-one (L-39) in Mice: An Inhibitor of Androgen Synthesis. British Journal of Cancer 2000;83(1): 74-82.

[95] Nnane I P, Njar V C O and Brodie A M H. Pharmacokinetics of Novel Inhibitors of Androgen Synthesis After Intravenous Administration in Mice. Cancer Chemotherapy and Pharmacology 2003;51(6): 519-524.

[96] Wolfling J, Oravecz E A, Ondre D, Mernyak E, Schneider G, Toth I, Szecsi M and Julesz J. Stereoselective Synthesis of Some 17 $\beta$-Dihydrooxazinyl Steroids, as Novel Presumed Inhibitors of $17 \alpha$-Hydroxylase- $\mathrm{C}_{17,20}$-Lyase. Steroids 2006;71: 809-816.

[97] Ondre D, Wölfling J, Iványi Z, Schneider G, Tóth I, Szécsi M and Julesz J. Neighboring group participation. Part 17 Stereoselective synthesis of some steroidal 2-oxazolidones, as novel potential inhibitors of $17 \alpha$-hydroxylase-C17,20-lyase. Steroids 2008;73: 1375-1384.

[98] Ondre D, Wölfling J, Tóth I, Szécsi M, Julesz J and Schneider G. Steroselective synthesis of some steroidal oxazolines, as novel potential inhibitors of $17 \alpha$-hydroxylaseC17,20-lyase. Steroids 2009;74: 1025-1032.

[99] Frank E, Mucsi Z, Szecsi M, Zupko I, Wolfling J and Schneider G. Intramolecular approach to some new D-ring-fused steroidal isoxazolidines by 1,3-dipolar cycloaddition: synthesis, theoretical and in vitro pharmacological studies. New Journal of Chemistry 2010;34: 2671-2681.

[100] Iványi Z, Wölfling J, Görbe T, Szécsi M, Wittmann T and Schneider G. Synthesis of regioisomeric $17-N$-phenylpyrazolyl steroid derivatives and their inhibitory effect on 17 $\alpha$-hydroxylase/C17,20-lyase. Steroids 2010;75: 450-456.

[101] Njar V C, Klus G T and Brodie A M H. Nucleophilic Vinylic "Addition-elimination" Substitution Reaction of 3 $\beta$-Acetoxy-17-chloro-16-formylandrosta-5,16-diene: A Novel and General Route to 17-Substituted Steroids. Part 1 - Synthesis of Novel 17-Azolyl- $\Delta^{16}$-steroids; Inhibitors of $17 \alpha$-Hydroxylase/17,20-Lyase (17 $\alpha$-Lyase). Bioorganic \& Medicinal Chemistry Letters 1996;6(22): 2777-2782. 
[102] Njar V C, Kato K, Nnane I P, Grigoryev D N, Long B J and Brodie A M. Novel 17Azolyl Steroids, Potent Inhibitors of Human Cytochrome $17 \alpha$-Hydroxylase- $\mathrm{C}_{17,20^{-}}$ Lyase $\left(\mathrm{P}_{450}{ }_{17} \alpha\right)$ : Potential Agents for the Treatment of Prostate Cancer. Journal of Medicinal Chemistry 1998;41(6): 902-912.

[103] Brodie A and Njar V C. 17-Azolyl Steroids Useful as Androgen Synthesis Inhibitors. US Patent 6,200,965 B1; 2001.

[104] Handratta V D, Jelovac D, Long B J, Kataria R, Nnane I P, Njar V C and Brodie A M. Potent CYP17 Inhibitors: Improved Syntheses, Pharmacokinetics and Anti-tumor Activity in the LNCaP Human Prostate Cancer Model. Journal of Steroid Biochemistry and Molecular Biology 2004;92(3): 155-165.

[105] Handratta V D, Vasaitis T S, Njar V C, Gediya L K, Kataria R, Chopra P, Newman D, Farquhar R, Guo Z, Qiu Y and Brodie A M. Novel C17-Heteroaryl Steroidal CYP17 Inhibitors/Antiandrogens: Synthesis, in vitro Biological Activity, Pharmacokinetics, and Antitumor Activity in the LAPC4 Human Prostate Cancer Xenograft Model. Journal of Medicinal Chemistry 2005;48(8): 2972-2984.

[106] Brodie A and Njar V C. Novel C-17-Heteroaryl Steroidal CYP17 Inhibitors/Antiandrogens: Synthesis, in vitro Biological Activities, Pharmacokinetics and Antitumor Activity. WO Patent 2006/093993; 2006.

[107] Barrie S E, Jarman M, Potter G A and Hardcastle I R. 17-Substituted Steroids Useful in Cancer Treatment. US Patent 5,604, 213; 1997.

[108] Grigoryev D N, Long B J, Nnane I P, Njar V C, Liu Y and Brodie A M. Effects of New $17 \alpha$-Hydroxylase/C17,20-Lyase Inhibitors on LNCaP Prostate Cancer Cell Growth in vitro and in vivo. British Journal of Cancer 1999;81(4): 622-630.

[109] Nnane I P, Njar V C, Liu Y, Lu Q and Brodie A M. Effects of Novel 17-Azolyl Compounds on Androgen Synthesis in vitro and in vivo. Journal of Steroid Biochemistry and Molecular Biology 1999;71(3-4): 145-152.

[110] Brodie A and Jisong L. 20-Substituted Pregnene Derivatives and Their Use as Androgen Inhibitors. US Patent 5,264,427; 1993.

[111] Li J S, Li Y, Son C and Brodie A M. Synthesis and Evaluation of Pregnane Derivatives as Inhibitors of Human Testicular $17 \alpha$-Hydroxylase $/ C_{17,20}$-Lyase. Journal of Medicinal Chemistry 1996;39(21): 4335-4339.

[112] Hartmann R W, Hector M, Haidar S, Ehmer P B, Reichert W and Jose J. Synthesis and Evaluation of Novel Steroidal Oxime Inhibitors of P450 $17\left(17 \alpha\right.$-Hydroxylase/ $\mathrm{C}_{17,20^{-}}$ Lyase) and 5 $\alpha$-Reductase Types 1 and 2. Journal of Medicinal Chemistry 2000;43(22): 4266-4277.

[113] Haidar S, Klein C D and Hartmann R W. Synthesis and Evaluation of Steroidal Hydroxamic Acids as Inhibitors of P450 17 (17 $\alpha$-Hydroxylase/ $\mathrm{C}_{17,20}$-Lyase). Archiv der Pharmazie (Weinheim) 2001;334(4): 138-140. 
[114] Li J, Li Y, Son C, Banks P and Brodie A. 4-Pregnene-3-one-20 $\beta$-carboxaldehyde: A Potent Inhibitor of $17 \alpha$-Hydroxylase $/ C_{17,20}$-Lyase and of $5 \alpha$-Reductase. Journal of Steroid Biochemistry and Molecular Biology 1992;42(3-4): 313-320.

[115] Njar V C, Hector M and Hartmann R W. 20-Amino and 20,21-Aziridinyl Pregnene Steroids: Development of Potent Inhibitors of $17 \alpha$-Hydroxylase/ $\mathrm{C}_{17,20}$-Lyase (P450 17). Bioorganic \& Medicinal Chemistry 1996;4(9): 1447-1453.

[116] Hartmann R W, Hector M, Wachall B G, Palusczak A, Palzer M, Huch V and Veith M. Synthesis and Evaluation of 17-Aliphatic Heterocycle-substituted Steroidal Inhibitors of $17 \alpha$-Hydroxylase/ $\mathrm{C}_{17,20}$-Lyase (P450 17). Journal of Medicinal Chemistry 2000;43(23): 4437-4445.

[117] Neubauer B L, Best K L, Blohm T R, Gates C, Goode R L, Hirsch K S, Laughlin M E, Petrow V, Smalstig E B, Stamm N B, Toomey R E and Hoover D M. LY207320 (6Methylene-4-pregnene-3,20-dione) Inhibits Testosterone Biosynthesis, Androgen Uptake, 5 $\alpha$-Reductase, and Produces Prostatic Regression in Male-Rats. Prostate 1993;23(3): 181-199.

[118] Njar V C, Klus G T, Johnson H H and Brodie A M. Synthesis of Novel 21-Trifluoropregnane Steroids: Inhibitors of 17 $\alpha$-Hydroxylase/17,20-Lyase (17 $\alpha$-Lyase). Steroids 1997;62(6): 468-473.

[119] Burkhart J P, Weintraub P M, Gates C A, Resvick R J, Vaz R J, Friedrich D, Angelastro M R, Bey P and Peet N P. Novel Steroidal Vinyl Fluorides as Inhibitors of Steroid $C_{17(20)}$-Lyase. Bioorganic \& Medicinal Chemistry 2002;10(4): 929-934.

[120] Peet N P, Weintraub P M, Burkhart J P and Gates C. 20-Fluoro-17(20)-Vinyl steroids as Inhibitors of $C_{17,20}$-Lyase and $5 \alpha$-Reductase. WO Patent 02/00681 A1; 2002.

[121] Peet N P, Weintraub P M, Burkhart J P and Gates C. 20-Fluoro-17(20)-Vinyl Steroids. US Patent 6,413,951 B2; 2002.

[122] Weintraub P M, Holland A K, Gates C A, Moore W R, Resvick R J, Bey P and Peet N P. Synthesis of 21,21-Difluoro-3 $\beta$-hydroxy-20-methylpregna-5,20-diene and 5,16,20Triene as Potential Inhibitors of Steroid $C_{17(20)}$-Lyase. Bioorganic \& Medicinal Chemistry 2003;11(3): 427-431.

[123] Deadman J J, McCague R, and Jarman M. Heptafluoro- $p$-tolyl as a protecting group in a synthesis of 3-hydroxy-17a-aza-17a-homopregn-5-en-20-one. A potential inhibitor of androgen biosynthesis. Journal of the Chemical Society, Perkin Transactions 1 1991;(10): 2413-2416.

[124] Curran T T, Flynn G A, Rudisill D E and Weintraub P M. A Novel Route to a 4-Amino Steroid - MDL 19687. Tetrahedron Letters 1995;36(27): 4761-4764.

[125] Li J, Li Y, Son C and Brodie A M. Inhibition of Androgen Synthesis by 22-Hydroximino-23,24-Bisnor-4-cholen-3-one. Prostate 1995;26(3): 140-150. 
[126] Barrie S E, Potter G A, Goddard P M, Haynes B P, Dowset M, Jarman M. Pharmacology of novel steroidal inhibitors of cytochrome $\mathrm{P}_{450_{17 \alpha}}$ (17 $\alpha$-hydroxylase C17-20 lyase). Journal of Steroid Biochemistry and Molecular Biology 1994;50(5-6): 267-273.

[127] Jarman M, Barrie S E and Llera J M. The 16,17-Double Bond Is Needed for Irreversible Inhibition of Human Cytochrome P450 $17 \alpha$ by Abiraterone (17-(3-Pyridyl)androsta-5,16-dien-3 $\beta$-ol) andRelated Steroidal Inhibitors. Journal of Medicinal Chemistry 1998;41(27): 5375-5381.

[128] Molina A and Belldegrun A. Novel Therapeutic Strategies for Castration Resistant Prostate Cancer: Inhibition of Persistent Androgen Production and Androgen Receptor Mediated Signaling. Journal of Urology 2011;185: 787-794.

[129] O'Donnell A, Judson I, Dowset M, Raynaud F, Dearnaley D, Mason M, Harland S, Robbins A, Halbert G, Nutley B and Jarman M. Hormonal impact of the $17 \alpha$-hydroxylase/ $\mathrm{C}_{17,20}$-lyase inhibitor abiraterone acetate (CB7630) in patients with prostate cancer. British Journal of Cancer 2004;90: 2317-2325.

[130] Eichholz A, Ferraldeschi R, Attard G and de Bono J S. Putting the brakes on continued androgen receptor signaling in castration-resistant prostate cancer. Molecular and Cellular Endocrinology 2012;360: 68-75.

[131] Attard G, Reid AH, Yap TA, Raynaud F, Dowsett M, Settatree S, Barrett M, Parker C, Martins V, Folkerd E, Clark J, Cooper CS, Kaye SB, Dearnaley D, Lee G and de Bono JS. Phase I clinical trial of a selective inhibitor of CYP17, abiraterone acetate, confirms that castration-resistant prostate cancer commonly remains hormone driven. Journal of Clinical Oncology 2008;26(28): 4563-4571.

[132] Ryan CJ, Smith MR, Fong L, Rosenberg JE, Kantoff P, Raynaud F, Martins V, Lee G, Kheoh T, Kim J, Molina A and Small EJ. Phase I clinical trial of the CYP17 inhibitor abiraterone acetate demonstrating clinical activity in patients with castration-resistant prostate cancer who received prior ketoconazole therapy. Journal of Clinical Oncology 2010;28(9): 1481-1488.

[133] Attard G, Reid AH M, A'Hern R, Parker C, Oommen NB, Folkerd E, Messiou C, Molife LR, Maier G, Thompson E, Olmos D, Sinha R, Lee G, Dowsett M, Kaye SB, Dearnaley D, Kheoh T, Molina A and de Bono JS. Selective inhibition of CYP17 with abiraterone acetate is highly active in the treatment of castration-resistant prostate cancer. Journal of Clinical Oncology 2009;27(23): 3742-3748.

[134] Danila DC, Morris MJ, de Bono JS, Ryan CJ, Denmeade SR, Smith MR, Taplin ME, Bubley GJ, Kheoh T, Haqq C, Molina A, Anand A, Koscuiszka M, Larson SM, Schwartz L H, Fleisher M and Scher HI. Phase II multicenter study of abiraterone acetate plus prednisone therapy in patients with docetaxel-treated castration-resistant prostate cancer. Journal of Clinical Oncology 2010;28(9): 1496-1501.

[135] Reid AH, Attard G, Danila DC, Oommen NB, Olmos D, Fong PC, Molife LR, Hunt J, Messiou C, Parker C, Dearnaley D, Swennenhuis JF, Terstappen LW, Lee G, Kheoh T, 
Molina A, Ryan CJ, Small E, Scher H I and de Bono JS. Significant and sustained antitumor activity in post-docetaxel, castration-resistant prostate cancer with the CYP17 inhibitor abiraterone acetate. Journal of Clinical Oncology 2010;28(9): 1489-1495.

[136] de Bono JS, Logothetis CJ, Molina A, Fizazi K, North S, Chu L, Chi KN, Jones RJ, Goodman OB Jr, Saad F, Staffurth JN, Mainwaring P, Harland S, Flaig TW, Hutson TE, Cheng T, Patterson H, Hainsworth JD, Ryan CJ, Sternberg CN, Ellard SL, Fléchon A, Saleh M, Scholz M, Efstathiou E, Zivi A, Bianchini D, Loriot Y, Chieffo N, Kheoh T, Haqq C M and Scher HI. Abiraterone and increased survival in metastatic prostate cancer. The New England Journal of Medicine 2011;364(21): 1995-2005.

[137] ClinicalTrials.gov: US National Institute of Health. www.ClinicalTrials.gov (accessed 27 July 2012).

[138] Vasaitis T, Belosay A, Schayowitz A, Khandelwal A, Chopra P, Gediya LK, Guo Z, Fang HB, Njar VC O and Brodie AM H. Androgen receptor inactivation contributes to antitumor efficacy of $17 \alpha$-hydroxylase/17,20-lyase inhibitor $3 \beta$-hydroxy-17-(1Hbenzimidazole-1-yl)androsta-5,16-diene in prostate cancer. Molecular Cancer Therapeutics 2008;7(8):2348-2357.

[139] Schayowitz A, Sabnis G, Njar V C O and Brodie A M H. Synergistic effect of a novel antiandrogen, $\mathrm{VN} / 124-1$, and signal transduction inhibitors in prostate cancer progression to hormone independence in vitro. Molecular Cancer Therapeutics 2008;7(1): 121-132.

[140] Schayowitz A, Sabnis G, Goloubeva O, Njar V C O and Brodie A M H. Prolonging hormone sensitivity in prostate cancer xenografts through dual inhibition of AR and mTOR. British Journal ofCancer 2010;103(7): 1001-1007.

[141] Soifer HS, Souleimanian N, Wu S, Voskresenskiy AM, Collak F K, Cinar B and Stein CA.Direct Regulation of Androgen Receptor Activity by Potent CYP17 Inhibitors in Prostate Cancer Cells. Journal of Biological Chemistry 2012;287(6): 3777-3787.

[142] Bruno RD, Vasaitis TS, Gediya LK, Purushottamachar P, Godbole AM, Ates-Alagoz $\mathrm{Z}$, Brodie AM H and Njar VC O. Synthesis and biological evaluations of putative metabolically stable analogs of VN/124-1 (TOK-001): Head to head anti-tumor efficacy evaluation of VN/124-1 (TOK-001) and abiraterone in LAPC-4 human prostate cancer xenograft model. Steroids 2011;76(12): 1268-1279. 